\title{
Phytotherapeutic potential of bi-herbal extract of cinnamon and turmeric: in vivo antidiabetic studies
}

\author{
R. Sivaranjani", T. John Zachariah and N. K. Leela
}

\begin{abstract}
Background: The spices, cinnamon and turmeric have both culinary and pharmaceutical applications. Earlier studies proved their effect on reducing the symptoms associated with type 2 diabetes, a major lifestyle disease affecting millions world over. In our work, we prepared a bi-herbal extract of cinnamon and turmeric and studied its effect to alleviate the symptoms of type 2 diabetes in rat model.

Method: The phenolic rich bi-herbal extract was given to diabetes induced male wistar rats for 28 days at two different concentrations (50 and $150 \mathrm{mg} / \mathrm{Kg}$ bwt.). The changes in blood glucose level were monitored at weekly interval. At the end of the experiment, blood serum was collected and used for the estimation of lipid profile, Glucose, aspartate aminotransferase (AST), alanine aminotransferase (ALT), alkaline phosphatase (ALP), Total Protein (TP), Albumin, Urea and Creatinine levels.

Result: The serum analysis revealed that administration of the bi-herbal extract at $150 \mathrm{mg} / \mathrm{Kg}$ bwt. significantly reduced the blood glucose level $(152.60 \pm 40.2 \mathrm{mg} / \mathrm{dL} ; p<0.05)$ of diabetic animals as compared to diabetic control $(335.40 \pm 67.3 \mathrm{mg} / \mathrm{dL} ; p<0.05)$ at the end of 4 weeks. The treatment also resulted in the reduction of total cholesterol and LDL-cholestrol levels as compared to diabetic control animals. The histopathological examination of tissues showed the improvement in pancreatic architecture and restoration of tissue integrity in liver and kidney.

Conclusion: The study concludes that methanol extract of combination of cinnamon and turmeric has good hypoglycemic, hypolipidemic and organ protective potential in diabetic rats which could be developed into functional food supplementation for the prevention of type 2 diabetes.
\end{abstract}

Keywords: Cinnamon, Turmeric, Streptozotocin, Antidiabetic, Wistar rats

\section{Background}

Non-Insulin Dependent Diabetes Mellitus (NIDDM) popularly known as Type- 2 diabetes is a biochemical metabolic disorder wherein the ability of cells to utilize blood glucose is reduced leads to metabolic abnormalities [1]. By 2025, around 300 million people were estimated to be affected by diabetes mellitus [2]. People with Insulin-Dependent Diabetes Mellitus (IDDM), otherwise known as Type-1 diabetes have to rely on

\footnotetext{
* Correspondence: ranjanigop@gmail.com

Division of Crop Production and Post-Harvest Technology, ICAR - Indian Institute of Spices Research, Kozhikode, Kerala 673012, India
}

insulin injection throughout their life, whereas incidence of NIDDM can be reduced through changes in food habits and lifestyle [3]. Since NIDDM is a complex metabolic disorder, single drug treatment options are found to be not effective; moreover prolonged use of synthetic drugs could lead to adverse health impacts. Hence, the search for new phytotherapeutic agents from natural sources in the form of bioactive compounds has assumed global significance [4]. In this regard, herbs and spices are emerged as panacea for many ailments occurring due to lifestyle modifications.

True Cinnamon, scientifically known as Cinnamomum zeylenium or Cinnamomum verum is reported to have

\section{Springer Open}

(c) The Author(s). 2021 Open Access This article is licensed under a Creative Commons Attribution 4.0 International License, which permits use, sharing, adaptation, distribution and reproduction in any medium or format, as long as you give appropriate credit to the original author(s) and the source, provide a link to the Creative Commons licence, and indicate if changes were made. The images or other third party material in this article are included in the article's Creative Commons licence, unless indicated otherwise in a credit line to the material. If material is not included in the article's Creative Commons licence and your intended use is not permitted by statutory regulation or exceeds the permitted use, you will need to obtain permission directly from the copyright holder. To view a copy of this licence, visit http://creativecommons.org/licenses/by/4.0/. 
numerous biological activities including antifungal, antimicrobial, antioxidant, anticancerous, antiviral, antidiabetic and immunomodulatory activities, to name a few [5-8] validated through both in vitro and in vivo assays. Few clinical studies in humans also proved its effect against type 2 diabetes $[9,10]$. Hayward et al. [11] compared the anti-hyperglycaemic properties of the four major commercial cinnamon types used around the world namely Cinnamomum cassia (Chinese cinnamon), C. burmanii (Indonesian cinnamon), C. loureirii (Vietnamese cinnamon) and C. zeylanicum (Ceylon cinnamon). Among them, C. zeylanicum showed the greatest potential to inhibit the formation of advanced glycation end products (AGEs) during digestion thus proved its antihyperglycemic activity. Cinnamon contains numerous bioactive compounds of phenolics and flavonoids category which individually or synergistically found to have antidiabetic properties [8].

Like cinnamon, the golden spice turmeric is also reported to have multifaceted biological activities including antidiabetic potential [12]. The mode of action of curcumin, the phytocompound of interest from turmeric against diabetic signalling pathway was well-worked out in the past decade [13-16].

Few reports are available on the synergistic activity of plant based phenolics among themselves and also with other oral antidiabetic drugs for diabetes treatment [1721]. Yet, it is quite difficult to pinpoint the cause and effect relationship of individual phenolic compounds in the extract of combined spices on any disease models. The question of which spices to select for combination poses barriers which could be overcome by careful literature survey and associated traditional knowledge on use of those spices. Though individual extract of turmeric and cinnamon in reducing the effect of diabetes in experimental animals have established with numerous work, the combination of these two spices to that effect has not been tried so far. With this background, the present study was undertaken to study the effect of phenolic rich bi-herbal extract of cinnamon and turmeric on STZ induced diabetes in wistar rats.

\section{Materials and methods}

\section{Plant collection and preparation}

Turmeric variety, IISR Prathibha with high curcumin content $(\sim 5 \%)$ released from ICAR - IISR and dried bark of true cinnamon, Cinnamomum zeylenicum collected from Alakkode (Kannur) estate of Plantation Corporation of Kerala Limited were used in the study. The samples were identified and authenticated by the Institute's taxonomist. The dried samples of cinnamon and turmeric were coarsely ground and mixed in 2:1 ratio and were used in the preparation of sequential extracts through soxhlet apparatus. Among them, methanol extract (hereafter mentioned as CTE) has the highest total phenolic content and showed highest antioxidant activity (previously published work from our laboratory) [22], were taken for the present study. The suspension of the extract was prepared by dissolving it in 5\% DMSO, a universally accepted vehicle in oral feeding studies.

\section{HPLC quantification of curcuminoids and cinnamic acid in CTE}

CTE was dissolved completely in HPLC grade methanol in the concentration of $1 \mathrm{mg} / \mathrm{mL}$ and filtered using $0.45 \mu \mathrm{m}$ filter before injecting into HPLC. The separation of curcuminoids was achieved in Purospher ${ }^{\mathrm{Th}}$ RP C18 column with the dimension of $150 \times 4.6 \mathrm{~mm}, 5 \mu \mathrm{m}$ (Merck, Germany) using a shimadzu LC-20 HPLC system (Shimadzu, Kyoto, Japan) consists of a binary pumping system and photodiode array (PDA) detector. The mobile phase used was Acetonitrile and $0.1 \%$ orthophosphoric acid (50:50) and eluted at a flow rate of $1 \mathrm{~mL} / \mathrm{min}$ in an isocratic mode. The resulting chromatogram data was processed using shimaduz LC solution 3.6 software. Elution of the compounds was monitored at $425 \mathrm{~nm}$ for curcuminoids and $274 \mathrm{~nm}$ for cinnamic acid and concentration of these compounds were calculated by comparing the peak area of the standards. The CTE did not contain cinnamaldehyde. We hypothesized that the rigorous process involved in the extract preparation led to the loss of cinnamaldehyde in it.

\section{Experimental animals}

The experiment was undertaken at animal house facility of CARe - Keralam Ltd., Thrissur, Kerala following guidelines of Institute Animal Ethics Committee (CKL/ TOX/IAEC/2017-3/95). Thirty albino male wistar rats were utilized in this study. Animals were maintained under standard laboratory conditions $\left(22 \pm 3{ }^{\circ} \mathrm{C}\right.$ room temperature and $50-60 \%$ humidity) with alternating light and dark cycles of $12 \mathrm{~h}$. The rats were fed with pellet diet ad libitum and were acclimatized to laboratory conditions for 7 days prior to the experiment. Induction of diabetes was done using single intraperitoneal injection of $30 \mathrm{mg} / \mathrm{kg}$ bwt. of streptozotocin (STZ) dissolved in freshly prepared citrate buffer $(0.1 \mathrm{M}, \mathrm{pH} 4.5)$. Animals with fasting blood glucose over $200 \mathrm{mg} / \mathrm{dL}, 3$ days after STZ administration were considered diabetic and they were divided into five groups of 6 rats each for CTE treatment.

\section{Treatment details}

Group 1: Normal control

Group II: Diabetic control

Group III: CTE I (50 mg/kg bwt.) 
Group IV: CTE II (150 mg/kg bwt.)

Group V: Glibenclamide positive control $(5 \mathrm{mg} / \mathrm{kg}$ bwt.)

The acute oral toxicity study of the extract in female wistar rats at $2000 \mathrm{mg} / \mathrm{kg}$ bwt. did not reveal any clinical signs, mortalities and gross pathological changes due to toxicity (data not shown). Since the IAEC suggested using minimum animals, one lower dose and one higher dose was taken based on acute oral toxicity study. Treatment related changes in body weights and blood glucose was conducted on weekly basis.

\section{Blood glucose estimation}

Blood samples were collected by the tail-vein cut method and glucose levels were measured immediately in a Glucometer (OneTouch Select Simple ${ }^{\circ}$, Flextronics Industrial Co, Ltd., China) using glucose oxidaseperoxidase reactive strips. Fasting blood glucose levels were checked before commencing the treatment and were considered day 0 and thereafter readings were taken on every fortnightly interval to assess the effect of extract treatment on diabetic animals.

\section{Analysis of blood parameters}

At the end of treatment (on 28th day) all treatment group animals were fasted overnight and were euthanized by intraperitoneal injection of thiopental. Blood samples from each animal were collected immediately by cardiac puncture. Hematological parameters of the samples were measured using automatic hematology cell counter (Medonic M16/M20 M-Series Bulk Model, Boule's Diagnostics, Sweden).

\section{Analysis of serum biochemical parameters}

Blood samples collected by cardiac puncture were allowed to clot for $30 \mathrm{~min}$ at room temperature and serum was separated by centrifugation at $3000 \mathrm{rpm}$ for $15 \mathrm{~min}$. The serum was assayed for biochemical parameters like lipid profile, Glucose, aspartate aminotransferase (AST), alanine aminotransferase (ALT), alkaline phosphatase (ALP), Total Protein (TP), Albumin, Urea and Creatinine (Creat) using automatic clinical biochemistry analyzer (VitalabSelectra Junior ${ }^{\mathrm{me}}$, Elitech Group, Netherland) using manufacturer's protocol.

\section{Histopathological examination}

Tissue samples of pancreas, liver and kidney were collected from the euthanized animals and preserved in $10 \%$ neutral buffered formalin. The tissues were fixed in paraffin wax, sectioned and stained with Mayer's haematoxylin and $1 \%$ alcoholic - eosin dyes. Detailed gross examination was performed on the internal organs of all animals from the control and the treatment groups sacrificed at scheduled termination. Histopathological analysis of the stained tissue samples was done using light microscope.

\section{Statistical analysis}

All the results were expressed as mean \pm SEM. The data analysis were performed using statistical software package SPSS version 16 to determine the significant differences between treatments group using Duncan's multiple range comparison tests. All analysis and comparisons was evaluated at $1 \%$ and $5 \%$ significance level.

\section{Results \\ HPLC quantification of curcuminoids and cinnamic acid in CTE}

The three components of curcuminoids namely bisdemethoxycurcumin (BDMC), demethoxycurcumin (DMC), curcumin and trans-cinnamic acid was identified using authentic standards and spectral signatures of these compounds in a HPLC system with PDA detector. The CTE was found to contain $13.8 \mathrm{mg} / \mathrm{g}, 14.4 \mathrm{mg} / \mathrm{g}$ and $45.7 \mathrm{mg} / \mathrm{g}$ BDMC, DMC, curcumin respectively. The trans-cinnamic acid content was found to be $0.38 \mu \mathrm{g} / \mathrm{g}$ of sample. The chromatogram of separated compounds of CTE is given in Fig. 1.

\section{Effect of CTE on body weights and body weight changes} In our experiment, significant reduction in body weight among diabetes group animal was observed as compared to normal control animals $(P<0.01)$. The body weight of control group animals showed significant increase in the duration of study period. But, no treatment related changes in body weight and body weight gain in treatment groups were observed as compared to normal control group during the study period (Fig. 2).

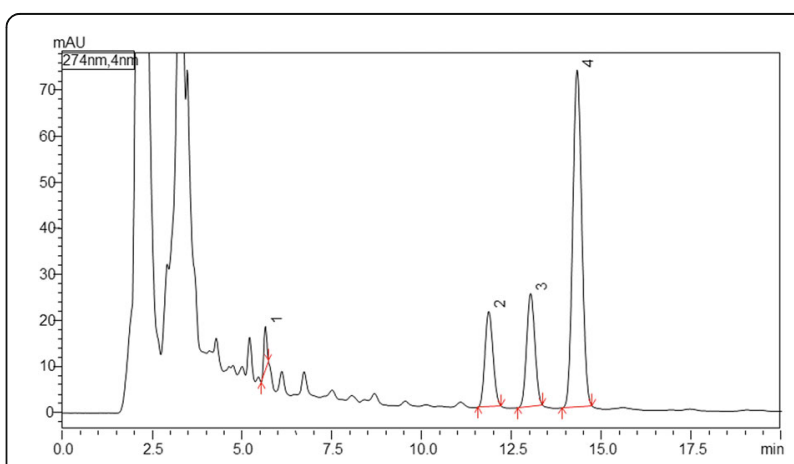

Fig. $1 \mathrm{HPLC}$ chromatogram of CTE (The chromatogram at $274 \mathrm{~nm}$ wavelength is represented here; 1 - cinnamic acid; 2 bisdemethoxycurcumin (BDMC); 3 - demethoxycurcumin (DMC); 4 - curcumin) 


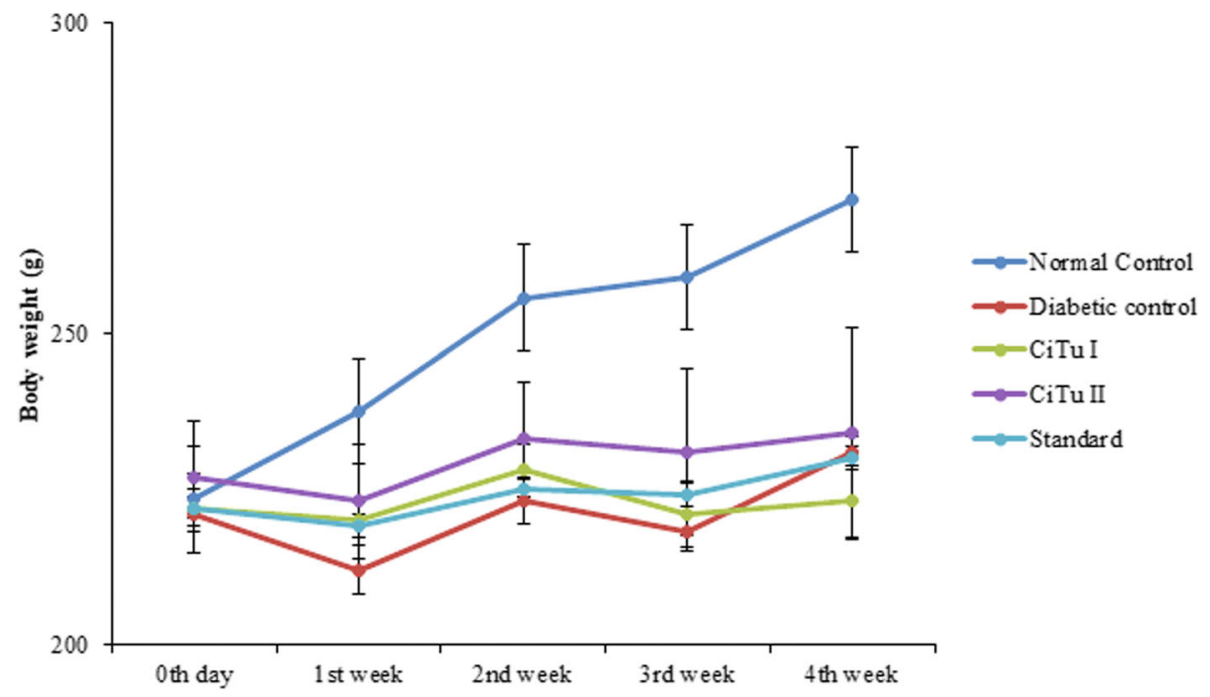

Fig. 2 Effect of CTE on body weight in different treatment group

\section{Effect of CTE on blood glucose levels}

There was significant increase in the blood glucose levels of diabetic control group as compared to normal control animals throughout the treatment period. A significant reduction $(p<0.05)$ in blood glucose levels were noted in the animals treated with CTE II $(152.60 \pm 40.2 \mathrm{mg} / \mathrm{dL})$ and standard drug $(138.80 \pm 33.8 \mathrm{mg} / \mathrm{dL})$ at the $4^{\text {th }}$ week of treatment as compared to diabetic control group $(335.40 \pm 67.3 \mathrm{mg} / \mathrm{dL})$. CTE II treatment showed $69 \%$ reduction in blood glucose level at $4^{\text {th }}$ week as compared to day 0 and $54.5 \%$ reduction as compared to the values of the diabetic control group. This reduction was comparable to positive control group (glibenclamide) which showed $72.2 \%$ and $58.6 \%$ as compared to day 0 and diabetic control group respectively. CTE I did not give significant reduction compared to diabetic control group (Fig. 3).

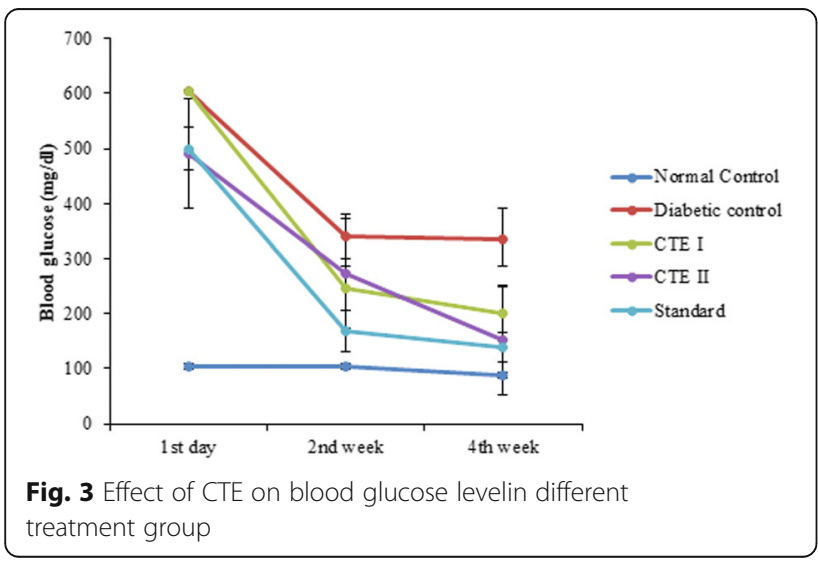

\section{Effect of CTE on haematological parameters}

There was marked reduction in hematological parameters in diabetic control group compared to normal control animals and statistically significant reduction was noted in RBC and Hematocrit (HCT) levels of diabetic control group animals $(p<0.05)$. There were slight elevation in hematological values of $\mathrm{RBC}, \mathrm{WBC}$ and platelet count in different treatment groups but the difference was not statistically significant (Table 1 ).

\section{Effect of CTE on serum biochemical parameters}

The serum glucose level was found to be higher in diabetic control group $(374.2 \pm 57.5 \mathrm{mg} / \mathrm{dl})$ whereas the CTE II treatment group showed significant $(p<0.05)$ reduction $(225.2 \pm 69.5 \mathrm{mg} / \mathrm{dl})$ in serum glucose level as comparable to glibenclamide treatment $(187.4 \pm 14.2 \mathrm{mg} /$ dl) group. Serum liver enzyme (AST, ALT and ALP) levels of the diabetic control groups were found to be significantly elevated as compared to normal control group. The treatment related significant normalization of ALT, AST and ALP levels $(p<0.01, p<0.05$ and $p<$ 0.01 respectively) was observed in both treatment group though CTE II group was found to be more efficient in its activity as the values are on par with glibenclamide treatment group. Serum proteins, total protein and albumin, were found to be significantly reduced in diabetic control group compared to the normal animals and any treatment related difference in these protein levels were not detected in various treatment groups. Serum urea levels were elevated in diabetic control animals $(p<0.01)$ compared to normal control group, but treatment related significant reduction urea levels were observed only in CTE II treatment groups $(p<0.05)$ (Table 2$)$. 
Table 1 Effect of CTE on haematological parameters

\begin{tabular}{|c|c|c|c|c|c|c|c|c|}
\hline Treatment groups & $\begin{array}{l}\text { RBC } \\
\left(10^{6} \text { cells } / \mathrm{mL}\right)\end{array}$ & $\mathrm{Hb}(\mathrm{g} / \mathrm{dL})$ & MCV (fi) & HCT (\%) & $\begin{array}{l}\text { WBC } \\
\left(10^{3} \text { cells } / \mathrm{ml}\right)\end{array}$ & $\mathrm{MCH}(\mathrm{pg})$ & $\begin{array}{l}\text { MCHC } \\
\text { (g/dL) }\end{array}$ & $\begin{array}{l}\text { Platelet } \\
\left(10^{6} \text { cells } / \mathrm{mL}\right)\end{array}$ \\
\hline Normal Control & $8.4 \pm 0.1^{\text {a }}$ & $16.9 \pm 0.7^{\mathrm{a}}$ & $54.3 \pm 1.3^{\mathrm{a}}$ & $46.0 \pm 0.9^{a}$ & $8.9 \pm 0.4$ & $20.2 \pm 0.1^{\mathrm{a}}$ & $37.2 \pm 0.4$ & $669.3 \pm 43.6$ \\
\hline Diabetic Control & $7.7 \pm 0.1^{c}$ & $15.3 \pm 0.5^{b}$ & $53.4 \pm 1.0^{\mathrm{ab}}$ & $41.2 \pm 0.7^{b}$ & $5.3 \pm 0.3$ & $19.9 \pm 0.1^{\mathrm{ab}}$ & $37.2 \pm 0.2$ & $535.2 \pm 17.9$ \\
\hline CTE I & $8.3 \pm 0.1^{\mathrm{ab}}$ & $16.2 \pm 0.3^{\mathrm{ab}}$ & $52.3 \pm 0.5^{b}$ & $42.9 \pm 0.4^{\mathrm{ab}}$ & $5.9 \pm 0.2$ & $19.6 \pm 0.1^{b}$ & $37.5 \pm 0.1$ & $613.2 \pm 19.4$ \\
\hline CTE II & $7.6 \pm 0.1^{c}$ & $15.1 \pm 0.4^{b}$ & $52.4 \pm 0.6^{b}$ & $39.7 \pm 0.5^{b}$ & $6.8 \pm 0.2$ & $20.0 \pm 0.1^{\mathrm{ab}}$ & $38.2 \pm 0.2$ & $649.8 \pm 36.4$ \\
\hline Glibenclamide positive control & $7.8 \pm 0.2^{b c}$ & $15.8 \pm 0.4^{\mathrm{ab}}$ & $52.3 \pm 1.1^{b}$ & $40.1 \pm 1.4^{b}$ & $7.6 \pm 0.6$ & $19.7 \pm 0.1^{b}$ & $37.1 \pm 0.4$ & $593.6 \pm 72.4$ \\
\hline
\end{tabular}

Different superscript $\left({ }^{\mathrm{a}, \mathrm{b}}\right)$ in the row indicate significant difference $(P<0.05)$ between treatments. Values are expressed as mean \pm SE of six replications

Serum lipid profiles were found to be markedly increased in diabetic control group compared to the normal animals and statistically significant elevation was noted in total cholesterol (TC) and low density lipoprotein (LDL) of diabetic control group animals $(p<0.05$ and $p<0.01$ respectively). Animals which received CTE II treatment $(p<0.01)$ and glibenclamide $(p<0.05)$ showed significant reduction in TC levels. LDL - cholesterol values were significantly reduced in animals treated with CTE I $(p<0.01)$, CTE II $(p<0.01)$ and glibenclamide $(p<0.01)$ (Fig. 4).

\section{Histopathological evaluation}

Microscopic examinations of the hematoxylin \& eosin stained rat tissue sections of pancreas, liver and kidney were done using light microscope. The pancreas of nondiabetic control (Group I) rats showed normal size and architecture with the exocrine component of pancreas closely packed by acinar cells and arranged into small lobules. The islet cells, source of insulin synthesis are visible as lightly stained cells surrounded by acinar cells. In diabetic control rats (Group II), islet cells were found reduced in size, damaged and with lymphocytes infiltration. The indicative features of pancreatic destruction like atrophy of islets, decrease in the $\beta$-cells, and cellular degeneration were also observed (Fig. 5). The structural changes in pancreas could change its metabolic processes of insulin secretion. In most of the rats treated with CTE I, CTE II and glibenclamide, islets architecture was found to be comparable to normal rats and there was not much shrinkage in size of the islet though slight damage was observed.

\section{Discussion}

Single drug regimen based treatments for diabetes has shortcomings like side effects, drug dependency leading to lifelong dosage and high rate of secondary failure. Since diabetes is a metabolic disorder involving numerous signal transduction pathways, the need for multitarget approach is the need of the hour. Phytochemicals present in some of the well-known crude plant extract could exert such influence in the diabetes signaling pathway as compared to single compound based conventional drugs. Our study was focused on the cumulative action of bi-herbal extract comprised of cinnamon and turmeric to explore the antidiabetic effect in STZ induced diabetic rats. STZ is a glucosamine-nitrosourea compound with alkylating property which is toxic to $\beta$ cells of pancreas in mammals. It is taken up via GLUT2 transporters present in the cell membrane and causes alkylation of DNA leads to death of $\beta$-cells causing type- 1 diabetic conditions [23]. Because of this action, it is used extensively in the induction of diabetes in experimental animal to analyze the effectiveness of antidiabetic drugs.

Phenolic acids are important classes of phytocompounds found in many herbs and spices. The derivatives of phenolic acids namely hydroxycinnamic acid and hydroxybenzoic acid based compounds are classified based on the position and number of hydroxyl groups on their aromatic ring. Cinnamic acid present in the $C$. zeylenicum acts as precursor for the synthesis of other phenolic acids namely caffeic, ferulic and sinapic acid [24]. This could explain the reason for lower concentration detected in CTE in our study. Due to lack of standards available, we could not quantify the other phenolic

Table 2 Effect of CTE on serum biochemical parameters

\begin{tabular}{|c|c|c|c|c|c|c|c|c|}
\hline Treatment groups & $\begin{array}{l}\text { Glucose } \\
\text { (mg/dL) }\end{array}$ & $\begin{array}{l}\text { Albumin } \\
\text { (g/dL) }\end{array}$ & ALP (U/L) & ALT (U/L) & AST (U/L) & $\begin{array}{l}\text { Creat } \\
\text { (g/dL) }\end{array}$ & $\begin{array}{l}\text { Protein } \\
\text { (mg/dL) }\end{array}$ & $\begin{array}{l}\text { Urea } \\
\text { (mg/dL) }\end{array}$ \\
\hline Normal Control & $92.8 \pm 5.5^{b}$ & $2.25 \pm 20.5^{\mathrm{a}}$ & $265.9 \pm 5.3^{c}$ & $46.1 \pm 28.4^{b}$ & $189.7 \pm 0.3^{b}$ & $0.2 \pm 0.1$ & $9.4 \pm 2.5^{\mathrm{a}}$ & $38.1 \pm 0.0^{b}$ \\
\hline Diabetic Control & $374.2 \pm 57.5^{\mathrm{a}}$ & $1.6 \pm 43.5^{b}$ & $735.1 \pm 7.6^{\mathrm{a}}$ & $84.4 \pm 70.5^{\mathrm{a}}$ & $316.7 \pm 0.4^{\mathrm{a}}$ & $0.25 \pm 0.1$ & $6.7 \pm 2.3^{b}$ & $62.7 \pm 0.0^{\mathrm{a}}$ \\
\hline CTE I & $314.5 \pm 81.9^{\mathrm{a}}$ & $1.9 \pm 24.8^{\mathrm{ab}}$ & $563.3 \pm 11.3^{\mathrm{ab}}$ & $67.8 \pm 88.9^{\mathrm{ab}}$ & $202.7 \pm 0.3^{b}$ & $0.24 \pm 0.1$ & $7.2 \pm 3.7^{b}$ & $56.5 \pm 0.0^{\mathrm{a}}$ \\
\hline CTE II & $225.2 \pm 69.5^{\mathrm{ab}}$ & $1.8 \pm 28.3^{b}$ & $448.0 \pm 7.8^{b c}$ & $47.5 \pm 72.4^{b}$ & $205.2 \pm 0.6^{\mathrm{ab}}$ & $0.25 \pm 0.1$ & $7.0 \pm 5.2^{b}$ & $50.0 \pm 0.0^{\mathrm{ab}}$ \\
\hline Glibenclamide positive control & $187.4 \pm 14.2^{\mathrm{ab}}$ & $1.9 \pm 20.0^{\mathrm{ab}}$ & $487.9 \pm 4.6^{\mathrm{abc}}$ & $38.5 \pm 86.8^{b}$ & $173.5 \pm 0.6^{\mathrm{b}}$ & $0.23 \pm 0.1$ & $7.9 \pm 5.4^{\mathrm{ab}}$ & $53.4 \pm 0.0^{\mathrm{ab}}$ \\
\hline
\end{tabular}




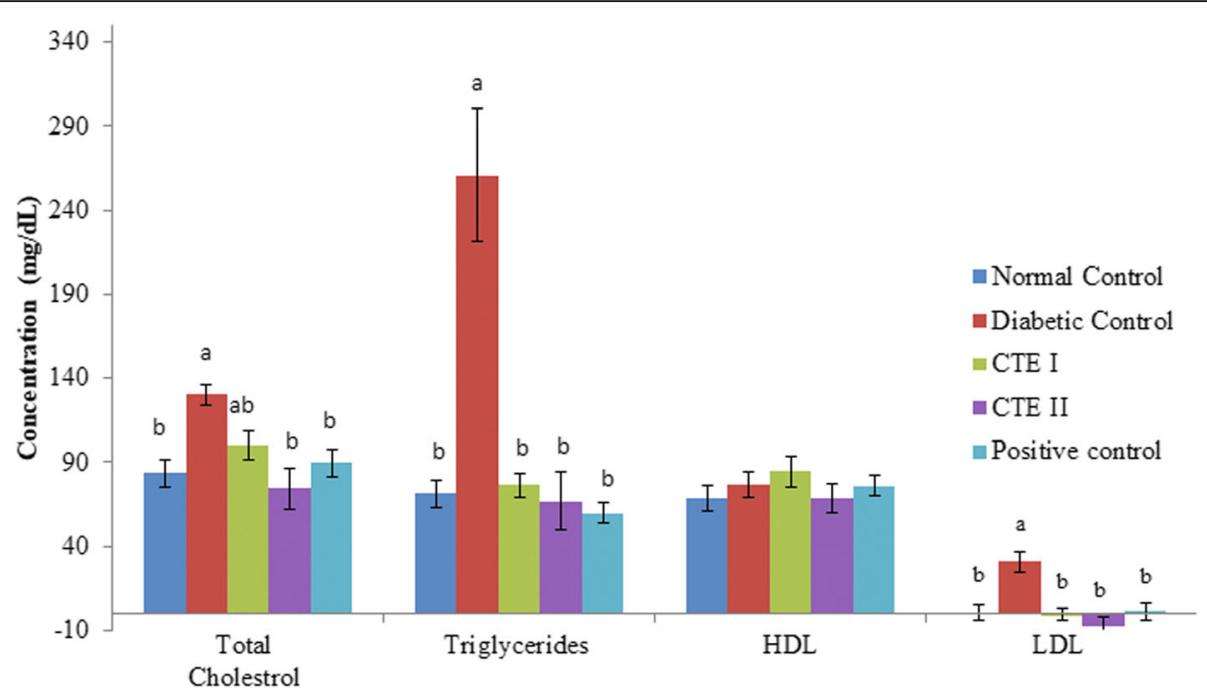

Fig. 4 Effect of CTE on serum lipid profile in different treatment group (Different superscript $\left({ }^{a, b}\right)$ in the row indicate significant difference $(p<$ $0.05)$ between treatments. Values are expressed as mean \pm SE of six replications)

acids in the present study. Bisdemethoxycurcumin (BDMC), demethoxycurcumin (DMC) and curcumin are the constituents of curcuminoids in the turmeric rhizome. Several studies indicating the positive effect of curcuminoids in alleviating the symptoms of diabetes like inhibition of $\alpha$-amylase enzyme, reduction in fasting blood glucose, cholesterol and low-density lipoprotein levels in both in vitro and in vivo models $[15,18,25$,
26]. However the relatively less bioavailability of curcuminoids prompted us to attempt the cumulative action of both extracts in alleviating the diabetic conditions. The blood glucose lowering effect of CTE observed in the present study could be attributed partly to these compounds.

The animals were monitored daily and/or weekly for symptoms of diabetes mellitus, including hyperglycemia,

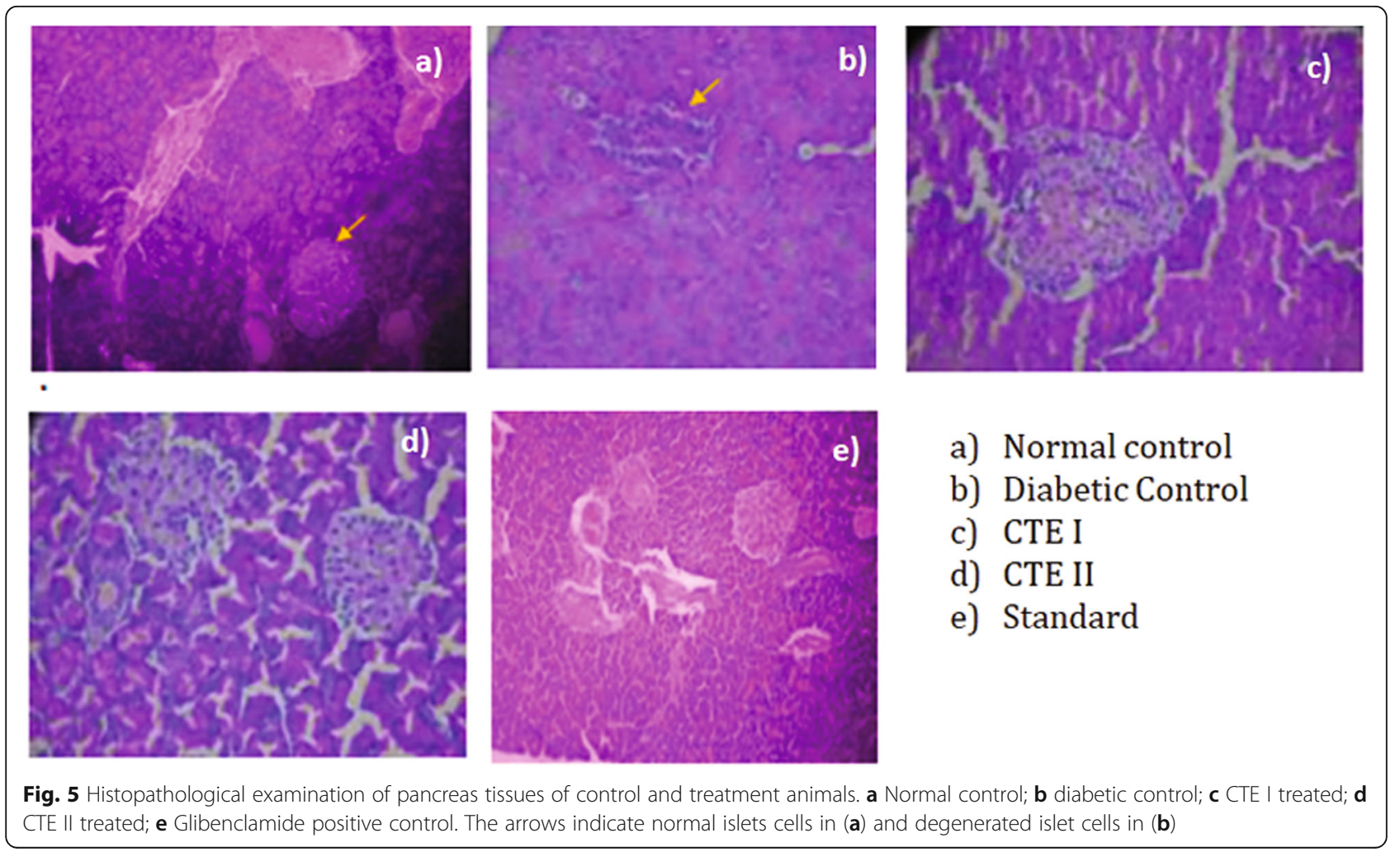


polydipsia, polyuria and muscle wasting throughout the experiment. The main characteristics of STZ induced diabetes in experimental animals is loss in body weight, due to absolute or relative deficiency of insulin manifested by apoptosis of pancreatic $\beta$-cells by STZ. Since insulin regulated signal transduction pathway involves switching on and switching off of enzymes involved in carbohydrate, protein and fat metabolism, in diabetic conditions, overproduction (excessive hepatic glycogenolysis and gluconeogenesis) and decrease in glucose utilization are observed. In our study, CTE treatment showed significant anti-hyperglycemic activity by bringing down the blood glucose level to near normal on day 28 in diabetic rats. Our results of significant reduction of blood glucose levels in diabetic rats by administration of herbal extract was in accordance with earlier reported results of similar nature $[27,28]$. Few studies were reported on the effect of supplementation of cinnamon and other herbs in type 2 diabetic populations proved to be effective in glycemic control $[9,10]$. The metabolites present in cinnamon namely cinnamaldehyde and methyl hydoxychalcone polymer were reported to have insulin-mimetic properties [29-31]. Though CTE did not contain cinnamaldehyde we found in the extract trans-cinnamic acid which also exerts antidiabetic effect. A study showed that trans-cinnamic acid treatment modulated glucose utilization and fat metabolism in diabetic condition through adiponectin stimulation and AMPK activation [32]. Oral administration of cinnamic acid was improved the glucose tolerance and reduced the blood glucose levels in diabetic rats [33]. Likewise, curcumin and other related phenylpropanoids reported to have glucose lowering activity in both animal and human trials [34, 35].

The CTE II treatment significantly reduced serum glucose level in consonance with earlier reported results [15, 34, 36, 37]. Mang et al. [38] reported the reduction in fasting blood glucose (FGB) level in the patients administered with aqueous cinnamon extract in a randomized controlled trial.

In our study, oral administration of CTE showed its protective nature on liver tissue by reducing the elevated levels of ALT and AST. The observed increase in serum AST and ALT levels in diabetic control group animals was due to STZ-induced liver necrosis which causes these enzymes to get leaked from liver cytosol into the blood stream. ALT and AST are common intracellular enzymes whose excretion in the blood is the clinical indication of liver damage induced by diabetes [38, 39]. The results observed in the present work are in coordination with histopathological results where partial restorations of liver tissues are observed in treated samples.

In diabetic condition, serum levels of TC, LDL, and TG increases, while the HDL levels decline, contributing to secondary complications. Acute insulin deficiency initially causes an increase in free fatty acid mobilization from adipose tissue. This results in an increased production of LDL [40]. In the present study, diabetic rats exhibited a significant elevation of TC and LDL. CTE extract administration resulted in lowering the serum levels of TC and LDL levels. Wang et al. [41] proved that administration of cinnamic acid and its nano-emulsion reduced blood glucose and cholesterol level in alloxaninduced diabetic rats. The turmeric and its active compound curcumin were reported to lower blood lipid levels especially LDL- cholesterol in patients with cardiovascular risk factors in human trials [42].

The present study corroborated the earlier reported findings and found a synergistic effect of turmeric and cinnamon in its effect on reducing serum lipid levels in diabetic rats. Apart from the above mentioned biochemical restoration, the curcumin of turmeric reported to have other multi-faceted benefits like alleviating diabetes induced neural and nephral changes [35, 43].

The treatment with CTE resulted in normalizing the pancreatic histoarchitecture quite appreciably. Likewise, the CTE treatment partially restored the tissue architecture of liver and kidney. The organ protective potential of CTE could be attributed to its higher phenolic content which acts as free-radical scavenger, which is considered as the major chemical induced tissue degeneration pathway [27, 44]. Over all, CTE was found to be effective in partial restoration of tissue damage and this fact could be explored for the treatment of patients with type 1 diabetes also.

\section{Conclusion}

The results of this study show that a bi-herbal extract of cinnamon and turmeric has significant hypoglycemic, hypolipidemic and organ protective potential in STZ induced diabetic rats. The extract at $150 \mathrm{mg} / \mathrm{kg}$ bwt. concentration significantly reduced the blood and serum glucose level and normalized other biochemical parameters. The important observation of the present work is the significant reduction in LDL-cholesterol level in both CTE I and CTE II extract treated animals, proved its effective hypolipidemic potential which could be tapped for the treatment of even non-diabetes associated hyperlipidemic conditions. The histopathological observation especially of pancreas proved its organ protective potential of the extract. The partial restoration of degenerated tissues of pancreas could be the reason for its antidiabetic activity and reduction in the necrosis of liver and kidney might have led to the normalization of serum enzymes. Thus, the bi-herbal methanol extract of cinnamon and turmeric could be promoted as food supplement or could be used to develop a drug or formulation for the management of diabetes mellitus. 


\section{Abbreviations}

ICAR: Indian Council of Agricultural Research; NIDDM: Non-Insulin Dependent Diabetes mellitus; IDDM: Insulin Dependent Diabetes mellitus; STZ: Streptozotocin; AGE: Active Glycation End products; IAEC: Institute Animal Ethics committee; CTE: Cinnamon Turmeric Methanol Extract; AST: Aspartate aminotransferase; ALT: Alanine aminotransferase; ALP: Alkaline phosphatase; SEM: Standard error of mean; RBC: Red blood cell; WBC: White blood cell; HCT: Hematocrit; TC: Total cholestrol; LDL: Low density lipoprotein; HDL: High density lipoprotein

\section{Supplementary Information}

The online version contains supplementary material available at https://doi. org/10.1186/s40816-021-00275-3.

\section{Additional file 1.}

\section{Acknowledgements}

Authors acknowledge ICAR for financial support and CARe-Keralam for conducting animal experiment at their facility.

\section{Authors' contributions}

All authors have contributed equally. All authors have read and approved the final manuscript

\section{Availability of data and materials}

All data generated or analysed during this study are included in this published article.

\section{Declarations}

\section{Ethics approval and consent to participate}

The study was approved by the IAEC of CARe - Keralam Ltd., Thrissur, Kerala.

\section{Consent for publication}

Not Applicable.

\section{Competing interests}

The authors declare that they have no competing interests.

Received: 26 November 2020 Accepted: 6 April 2021

Published online: 12 April 2021

\section{References}

1. Alberti KG, Zimmet PZ. Definition, diagnosis and classification of diabetes mellitus and its complications. I. Diagnosis and classification of diabetes mellitus provisional report of a WHO consultation. Diabet Med. 1998;15(7): 539-53. https://doi.org/10.1002/(SICI)1096-9136(199807)15:7<539::AID-DIA $668>3.0 . C O ; 2-S$

2. Pradeepa R, Deepa R, Mohan V. Epidemiology of diabetes in India-current perspective and future projections. J Indian Med Assoc. 2002;100(3):144-8.

3. Asif M. The prevention and control the type-2 diabetes by changing lifestyle and dietary pattern. J Educ Health Promot. 2014;3(1):1. https://doi.org/10.41 03/2277-9531.127541.

4. Chehade JM, Mooradian AD. A rational approach to drug therapy of type 2 diabetes mellitus. Drugs. 2000;60(1):95-113. https://doi.org/10.2165/000034 95-200060010-00006.

5. Baker WL, Gutierrez-Williams G, White CM, Kluger J, Coleman Cl. Effect of cinnamon on glucose control and lipid parameters. Diabetes Care. 2008; 31(1):41-3. https://doi.org/10.2337/dc07-1711.

6. Kurokawa M, Kumeda CA, Yamamura J, Kamiyama T, Shiraki K. Antipyretic activity of Cinnamyl derivatives and related compounds in influenza virus infected mice. Eur J Pharmacol. 1998;348(1):45-51. https://doi.org/10.1016/ s0014-2999(98)00121-6.

7. Mathew S, Abraham TE. Studies on the antioxidant activities of cinnamon (Cinnamomum verum) bark extracts, through various in vitro models. Food Chem. 2006;94(4):520-8. https://doi.org/10.1016/j.foodchem.2004.11.043.

8. Rao VP, Gan HS. Cinnamon: a multifaceted medicinal plant. Evid Based Complement Alternat Med. 2014. https://doi.org/10.1155/2014/642942.
9. Mirmiranpour H, Huseini HF, Derakhshanian H, Khodaii Z, Tavakolifar B. Effects of probiotic, cinnamon, and synbiotic supplementation on glycemic control and antioxidant status in people with type 2 diabetes; a randomized, double-blind, placebo-controlled study. J Diabetes Metab Disord. 2019;19(1):53-60. https://doi.org/10.1007/s40200-019-00474-3.

10. Rahmoun NM, Boukli-Hacene G, Bettioui RA, Ghembaza C, Gembaza ME. Effect of the consumption of natural products on some biochemical parameters of a type 2 diabetic population. J Diabetes Metab Disord. 2020; 19(1):233-41. https://doi.org/10.1007/s40200-020-00496-2.

11. Hayward NJ, McDougall G, Farag SJ, Allwood W, Austin C, Campbell F, et al. Cinnamon shows antidiabetic properties that are species-specific: effects on enzyme activity inhibition and starch digestion. Plant Foods Hum Nutr. 2019:74(4):544-52. https://doi.org/10.1007/s11130-019-00760-8.

12. Chattopadhyay I, Biswas K, Bandyopadhyay U, Banerjee RK. Turmeric and curcumin: biological actions and medicinal applications. Curr Sci. 2004;87(1): 44-53.

13. Chuengsamarn S, Rattanamongkolgul S, Phonrat B, Tungtrongchitr R, Jirawatnotai S. Reduction of atherogenic risk in patients with type 2 diabetes by curcuminoid extract: a randomized controlled trial. J Nutr Biochem. 2014;25(2):144-50. https://doi.org/10.1016/j.jnutbio.2013.09.013.

14. He HJ, Wang GY, Gao Y, Ling WH, Yu ZW, Jin TR. Curcumin attenuates Nrf2 signaling defect, oxidative stress in muscle and glucose intolerance in high fat diet-fed mice. World J Diabetes. 2012;3(5):94-104. https://doi.org/10.423 9/wjd.v3.15.94

15. Nishiyama T, Mae T, Kishida H, Tsukagawa M, Mimaki Y, Kuroda M, et al. Curcuminoids and sesquiterpenoids in turmeric (Curcuma longa L.) suppress an increase in blood glucose level in type 2 diabetic KK-Ay mice. J Agric Food Chem. 2005:53(4):959-63. https://doi.org/10.1021/jf0483873.

16. Seo K-I, Choi M-S, Jung UJ, Kim H, Yeo J, Jeon S, et al. Effect of curcumin supplementation on blood glucose, plasma insulin, and glucose homeostasis related enzyme activities in diabetic $\mathrm{db} / \mathrm{db}$ mice. Mol Nutr Food Res. 2008;52(9):995-1004. https://doi.org/10.1002/mnfr.200700184.

17. Abdel Raoof GF, Mohamed KY, Mohammed HM. Phytochemical evaluation, anti-obesity and antihyperlipidemic effects of combined administration of green coffee, cinnamon and ginger. Plant. 2017;5(5):80-4. https://doi.org/1 0.11648/j.plant.20170505.12.

18. Ali Hussain HEM. Hypoglycemic, hypolipidemic and antioxidant properties of combination of Curcumin from Curcuma longa, Linn, and partially purified product from Abroma augusta, Linn. in streptozotocin induced diabetes. Indian J Clin Biochem. 2002;17(2):33-43. https://doi.org/10.1007/ BF02867969.

19. ElSadek MF, Almajwal AM, Abulmeaty MMA. Antioxidant effects of ginger, cinnamon and combination on Streptozotocin-induced hyperglycemia associated oxidative stress in rats. Prog Nutr. 2016;18(4):421-8.

20. Prabhakar PK, Doble M. Interaction of phytochemicals with hypoglycemic drugs on glucose uptake in L6 myotubes. Phytomedicine. 2011;18(4):28591. https://doi.org/10.1016/.j.phymed.2010.06.016.

21. Upadhyay S, Dixit M. Role of polyphenols and other phytochemicals on molecular signaling. Oxid Med Cell Longev. 2015:504253. https://doi.org/1 $0.1155 / 2015 / 504253$

22. Sivaranjani R, Leela NK, Tejpal CS, Zachariah TJ. Dietary supplementation of Cinnamomum verum J. Presl and Curcuma longa $L$. extract on growth performance, antioxidant and metabolic enzymes activities in experimental rats. Indian J Exp Biol. 2020;58:242-8 http://nopr.niscair.res.in/handle/1234 $56789 / 54262$

23. Patel R, Shervington A, Pariente JA, Martinez-Burgos M, Salido GM, Adeghate $M$, et al. Mechanism of exocrine pancreatic insufficiency in streptozotocin-induced type 1 diabetes mellitus. Ann N Y Acad Sci. 2006; 1084(1):71-88. https://doi.org/10.1196/annals.1372.038.

24. Kim SH, Hyun SH, Choung SY. Anti-diabetic effect of cinnamon extract on blood glucose in db/db mice. J Ethnopharmacol. 2006;104(1-2):119-23. https://doi.org/10.1016/j.jep.2005.08.059.

25. Kalaycıoğlu Z, Gazioğlu I, Erim FB. Comparison of antioxidant, anticholinesterase, and antidiabetic activities of three curcuminoids isolated from Curcuma longa L. Nat Prod Res. 2017;31(24):2914-7. https://doi.org/1 0.1080/14786419.2017.1299727.

26. Ponnusamy S, Zinjarde S, Bhargava S, Rajamohanan PR, RaviKumar A. Discovering Bisdemethoxycurcumin from Curcuma longa rhizome as a potent small molecule inhibitor of human pancreatic a-amylase, a target for type-2 diabetes. Food Chem. 2012;135(4):2638-42. https://doi.org/10.1016/j. foodchem.2012.06.110. 
27. Quershi AS, Ghaffor J, Usman M, Ehsan N, Umar Z, Sarfraz A. Effect of ethanolic preparations of cinnamon (Cinnamomum zeylanicum) extract on hematologic and histometric parameters of selected organs in Alloxan ${ }^{\oplus}$ induced diabetic female albino rats. J Diabetes Metab Disord. 2019;18(2): 505-12. https://doi.org/10.1007/s40200-019-00457-4.

28. Sharma S, Kulkarni SK, Chopra K. Curcumin, the active principle of turmeric (Curcumalonga) ameliorates diabetic nephropathy in rats. Clin Exp Pharmaco Physiol. 2006;33(10):940-5. https://doi.org/10.1111/j.1440-1681.2006.04468.x.

29. Anderson RA, Broadhurst CL, Polansky MM, Schmidt WF, Khan A, Flanagan $V P$, et al. Isolation and characterization of polyphenol type-a polymers from cinnamon with insulin-like biological activity. J Agric Food Chem. 2004;52(1): 65-70. https://doi.org/10.1021/jf034916b.

30. Imparl-Radosevich J, Deas S, Polansky MM, Baedke DA, Inge-brutsen TS, Anderson RA, et al. Regulation of phosphotyrosine phosphatase (PTP-1) and insulin receptor kinase by fractions from cinnamon: implications for cinnamon regulation of insulin signaling. Hormone Res. 1998;50(3):177-82. https://doi.org/10.1159/000023270.

31. Jarvill-Taylor KJ, Anderson RA, Graves DJ. A Hydroxychalcone derived from cinnamon functions as a mimetic for insulin in 3T3-L1 adipocytes. J Am Coll Nutr. 2001;20(4):327-36. https://doi.org/10.1080/07315724.2001.10719053.

32. Kopp C, Singh SP, Reganhard P, Müller U, Sauerwein H, Mielenz M. Transcinnamic acid increases adiponectin and the phosphorylation of AMPactivated protein kinase through G-protein-coupled receptor signaling in 3T3-L1 adipocytes. Int J Mol Sci. 2014;15(2):2906-15. https://doi.org/10.33 90/ijms15022906.

33. Hafizur RM, Hameed A, Shukrana M, Raza SA, Chishti S, Kabir N, et al. Cinnamic acid exerts anti-diabetic activity by improving glucose tolerance in vivo and by stimulating insulin secretion in vitro. Phytomedicine. 2015; 22(2):297-300. https://doi.org/10.1016/j.phymed.2015.01.003.

34. Arun N, Nalini N. Efficacy of turmeric on blood sugar and polyol pathway in diabetic albino rats. Plant Foods Hum Nutr. 2002;57(1):41-52. https://doi. org/10.1023/A:1013106527829.

35. Peeyush KT, Gireesh G, Jobin M, Paulose CS. Neuroprotective role of curcumin in the cerebellum of streptozotocin-induced diabetic rats. Life Sci. 2009;85(19-20):704-10. https://doi.org/10.1016/j.lfs.2009.09.012.

36. Beji RS, Khemir S, Wannes WA, Ayari K, Ksouri R. Antidiabetic antihyperlipidemic and antioxidant influences of the spice cinnamon (Cinnamomum zeylanicum) in experimental rats. Braz J Pharm Sci. 2018;54(2). https://doi.org/10.1590/s2175-97902018000217576.

37. Narayannasamy A, Namasivayam N, Radha K. Effect of turmeric on the enzymes of glucose metabolism in diabetic rats. Int J Geogr Inf Syst. 2003; 10(1):75-84. https://doi.org/10.1300/j044v10n01_0.

38. Mang B, Wolters M, Schmitt B, Kelb K, Lichtinghagen R, Stichtenoth DO, et al. Effects of a cinnamon extract on plasma glucose, $\mathrm{HbA1c}$, and serum lipids in diabetes mellitus type 2. Euro J Clin Investig. 2006;36(5):340-4. https://doi.org/10.1111/j.1365-2362.2006.01629.x.

39. Giannini EG, Testa R, Savarino V. Liver enzyme alteration: a guide for clinicians. Can Med Assoc J. 2005;172(3):367-79. https://doi.org/10.1503/cmaj.1040752.

40. Murali B, Upadhyaya UM, Goyal RK. Effect of chronic treatment with Enicosistemma littorale in non-insulin-dependent diabetic (NIDDM) rats. J Ethnopharmacol. 2002;81(2):199-204. https://doi.org/10.1016/s0378-8741 (02)00077-6

41. Wang H, Li Q, Deng W, Omari-Siaw E, Wang Q, Wang S, et al. Selfnanoemulsifying drug delivery system of trans-cinnamic acid: formulation development and pharmacodynamic evaluation in alloxan-induced type 2 diabetic rat model. Drug Dev Res. 2015;76(2):82-93. https://doi.org/10.1002/ ddr.21244.

42. Qin S, Huang L, Gong J, Shen S, Huang J, Ren H, et al. Efficacy and safety of turmeric and curcumin in lowering blood lipid levels in patients with cardiovascular risk factors: a meta-analysis of randomized controlled trials. Nutr J. 2017;16(1). https://doi.org/10.1186/s12937-017-0293-y.

43. Sharma B, Balomajumder C, Roy P. Hypoglycemic and hypolipidemic effects of flavonoid rich extract from Eugenia jambolanaseeds on streptozotocin induced diabetic rats. Food Chem Toxicol. 2008:46(10):2376-83. https://doi. org/10.1111/j.1440-1681.2006.04468.x.

44. Atta AH, Elkoly TA, Mouneir SM, Kamel G, Alwabel NA, Zaher S. Hepatoprotective effect of methanol extracts of Zingiber officinale and Cichorium intybus. Indian J Pharm Sci. 2010;72(5):564-70. https://doi.org/1 0.4103/0250-474X.78521

\section{Publisher's Note}

Springer Nature remains neutral with regard to jurisdictional claims in published maps and institutional affiliations.

\section{Submit your manuscript to a SpringerOpen ${ }^{\circ}$ journal and benefit from:}

- Convenient online submission

- Rigorous peer review

- Open access: articles freely available online

High visibility within the field

- Retaining the copyright to your article

Submit your next manuscript at $\boldsymbol{\nabla}$ springeropen.com 